\title{
The sensitivity of bacterial foodborne pathogens to Croton blanchetianus Baill essential oil
}

\author{
Geiseanny Fernandes do Amarante Melo ${ }^{1}$, Ana Caroliny Vieira da Costa ${ }^{1}$, \\ Felício Garino Junior ${ }^{3}$, Rosália Severo Medeiros ${ }^{1}$, Marta Suely Madruga ${ }^{1}$, \\ Vicente Queiroga Neto ${ }^{2}$ \\ ${ }^{1}$ Departamento de Engenharia de Alimentos, Centro de Tecnologia, Universidade Federal da Paraíba, \\ João Pessoa, PB, Brazil. \\ ${ }^{2}$ Laboratório de Análise de Matérias Primas Agropecuária, Centro de Saúde e Tecnologia Rural, \\ Universidade Federal de Campina Grande, Campus Patos, Patos, PB, Brazil. \\ ${ }^{3}$ Laboratório de Microbiologia, Hospital Veterinário, Centro de Saúde e Tecnologia Rural, \\ Universidade Federal de Campina Grande, Campus Patos, PB, Brasil.
}

Submitted: October 13, 2011; Approved: April 4, 2013.

\begin{abstract}
The aim of this study was to assess the activity of essential oil extracted from the leaves of $C$. blanchetianus Baill, popularly known as "marmeleiro", in inhibiting the growth and survival of pathogenic microorganisms in food by determining their survival in vitro and by observing the behaviour of Listeria monocytogenes inoculated into a food model (meat cubes) that was stored at refrigeration temperature $\left(7 \pm 1{ }^{\circ} \mathrm{C}\right)$ for 4 days. The results indicated a bactericidal effect against Aeromonas hydrophila and Listeria monocytogenes and bacteriostatic action against Salmonella Enteritidis. A bacteriostatic effect on meat contaminated with L. monocytogenes was found for all concentrations of essential oils tested. These results showed that essential oil from the leaves of $C$. blanchetianus Baill represents an alternative source of potentially natural antimicrobial agents that may be used as a food preservative.
\end{abstract}

Key words: essential oil, Croton blanchetianus Baill, antimicrobial activity, foodborne microorganisms.

\section{Introduction}

Food preservation techniques are used to provide food with high nutritional quality and microbial stability, which is achieved by controlling the growth/survival of spoilage-associated and foodborne microorganisms (Baydar et al., 2004; Benkeblia, 2004). Historically, several physical and/or chemical procedures have been used to ensure the microbiological safety of foods (Daferera et al., 2003; Marino et al., 2001). Recently, the use of chemical food preservatives has been questioned, particularly by consumers who demand more natural foods (MendozaYepez et al., 1997; Radhrakrishanan-Sridhar et al., 2003). More than 1,340 plants are known as potential sources of antimicrobial compounds, but very few of these have been studied scientifically (Seidil, 2000).

This scenario has encouraged research aimed at the possible development and use of vegetable products with antimicrobial properties (Souza et al., 2005; Valero and Salmerón, 2003). Species from the genus Croton are frequently used in popular medicine (as infusions, teas and poultices) to relieve pain (Abreu et al., 2001), constipation, diarrhea and other digestive symptoms, diabetes, wounds, inflammation, fever, and hypertension (Salatino et al., 2007). Studies conducted in certain species have demonstrated several pharmacological properties of plants within this genus, such as antidiabetic (Barbosa-Filho et al., 2005), anti-inflammatory, antiulcerogenic, analgesic and 
anti-hypertensive activities (Palmeira-Junior et al., 2006), among others. C. blanchetianus Baill (synonym Croton sonderianus Müll. Arg.) (Govaerts et al., 2000), known as "black marmeleiro", is a widely disseminated shrub found in northeast Brazil. Its leaves and bark are used as popular medicines for treating gastrointestinal disturbances, rheumatism and cephalalgia (Chaves and Reinhard, 2003). It has a high essential oil content, and its yield may range from $0.5 \%$ to $1.5 \%$ (Chaves and Reinhard, 2003). Furthermore, this plant is rich in diterpenes with different biological activities, including anti-inflammatory, gastroprotective and antimicrobial properties (Marino et al., 2001).

The aim of this study was to evaluate the efficacy of essential oil from the leaves of $C$. blanchetianus Baill in inhibiting the growth of gram-positive and gram-negative pathogenic bacteria and to analyse the antibacterial effectiveness of $C$. blanchetianus Baill essential oil in meat cubes stored under refrigeration.

\section{Materials and Methods}

\section{Essential oil}

Fresh leaves of $C$. blanchetianus were collected in the rural municipality of Patos $\left(7^{\circ} 05^{\prime} 10^{\prime \prime} \mathrm{S}, 37^{\circ} 15^{\prime} 45^{\prime \prime} \mathrm{W}\right)$, located in the semiarid central region of Paraíba, Brazil, from February-March 2011. The species was identified by comparison with a herbarium specimen, and a dried sample (no. 1462) was deposited in the Brazil Herbarium, Federal University of Campina Grande, Patos, Paraíba.

Fresh leaves (150 g) were submitted to hydrodistillation for $3 \mathrm{~h}$ using a Clevenger type apparatus according to the method recommended in the European Pharmacopoeia (2004). The obtained oils were allowed to dry over anhydrous sodium sulphate. The oils were filtered and then stored at $4{ }^{\circ} \mathrm{C}$ prior to testing and analysis. The yield of the oil was $0.7 \%$. The essential oil was tested at concentrations ranging from 80-0.6 $\mu \mathrm{g} \cdot \mathrm{mL}^{-1}$. Essential oil solutions were prepared in Mueller Hinton broth (MH) (HiMed ${ }^{\circledR}$, Mumbai, India) using bacteriological agar $\left(0.15 \mathrm{~g} .100 \mathrm{~g}^{-1}\right)$ as a stabilising agent (Bennis et al., 2004; Mann and Markham, 1998).

\section{Bacterial strains}

Strains of Aeromonas hydrophila INCQS 7966, Listeria monocytogenes ATCC 7644 and Salmonella Enteritidis CDC 49812 were used as test microorganisms. Inocula used in antimicrobial assays were obtained from overnight cultures grown on $\mathrm{MH}$ agar slants at an optimum growth temperature $\left(28^{\circ} \mathrm{C}\right.$ for $A$. hydrophila and $37^{\circ} \mathrm{C}$ for the other bacteria). A loopful of the culture was diluted in sterile saline solution $\left(0.85\right.$ g. $\left.100 \mathrm{~mL}^{-1}\right)$ to a final concentration of approximately $10^{8}$ colony-forming units per $\mathrm{mL}$ (cfu. $\mathrm{mL}^{-1}$ ) adjusted according to the turbidity of $0.5 \mathrm{McFar}$ land standards. The final concentration of the inoculum in the medium used for the antimicrobial assays was approximately $10^{6}$ cfu. $\mathrm{mL}^{-1}$.

\section{Tests of cell viability}

Our previous experiments with $C$. blanchetianus Baill essential oil against the tested pathogens using disc diffusion revealed clearance zones of 10-12 mm and minimum inhibitory concentrations (MICs) of $20 \mu \mathrm{L} . \mathrm{mL}^{-1}$, $1.25 \mu \mathrm{L} . \mathrm{mL}^{-1}$ and $40 \mu \mathrm{L} . \mathrm{mL}^{-1}$ for Aeromonas hydrophila, Listeria monocytogenes and Salmonella Enteritidis, respectively (unpublished data). Cell counts were performed to test cell viability at concentrations of MIC/2, MIC and $2 \mathrm{x}$ MIC. For this purpose, $5 \mathrm{~mL}$ of double concentrated $\mathrm{MH}$ broth was inoculated with $1 \mathrm{~mL}$ of bacterial suspension. Next, $4 \mathrm{~mL}$ of $C$. blanchetianus Baill essential oil solution was added to obtain an appropriate final concentration, and the system was incubated at $37{ }^{\circ} \mathrm{C}$ under aerobiosis. At intervals of 0 min., $30 \mathrm{~min}, 1 \mathrm{~h}, 2 \mathrm{~h}, 4 \mathrm{~h}, 6 \mathrm{~h}, 8 \mathrm{~h}$ and $10 \mathrm{~h}$ after incubation, $1.0 \mathrm{~mL}$ aliquots of the suspension were diluted $\left(10^{-1}-10^{-5}\right)$ in sterile peptone water and uniformly seeded onto Petri plates containing $\mathrm{MH}$ agar using the plate spreading technique. After the incubation period, the viable cells were counted, and the resulting value was expressed in $\log$ cfu. $\mathrm{mL}^{-1}$. Control samples without essential oil were tested in parallel (Barros et al., 2009).

\section{Antimicrobial activity in a food model}

Bovine meat knuckles were trimmed of all external fat and cut into pieces of uniform sizes $(3 \times 3 \times 3 \mathrm{~cm})$. The meat pieces were placed in glass flasks and sterilised using an autoclave $\left(121{ }^{\circ} \mathrm{C}\right.$ for $\left.15 \mathrm{~min}, 121 \mathrm{~atm}\right)$. Then, meat pieces were inoculated with a microbial suspension by individual submersion in $50 \mathrm{~mL}$ of the bacterial inoculum $(L$. monocytogenes containing approximately $10^{8}$ cfu. $\mathrm{mL}^{-1}$, prepared in sterile $0.85 \mathrm{~g} .100 \mathrm{~mL}^{-1}$ saline solution) with rotation with a sterile glass rod for $1 \mathrm{~min}$ to ensure even inoculation. The inoculated pieces were air dried for $30 \mathrm{~min}$ in a bio-safety cabinet and finally washed with the essential oil (Oliveira et al., 2010). The inoculated pieces were randomly divided into five groups and treated for $30 \mathrm{~s}$ (1:4 w/v) as follows: (I) control, dipped in sterile distilled water; (II) dipped in 1x MIC essential oil solution; (III) dipped in 2x MIC essential oil solution; (IV) dipped in 5x MIC essential oil solution; and (V) dipped in 10x MIC essential oil solution. The pieces were then placed in sterile sealed polypropylene cups and stored under refrigeration $\left(7^{\circ} \mathrm{C} \pm 1^{\circ} \mathrm{C}\right)$. At $0,24,48,72$ and $96 \mathrm{~h}$ of storage, the meat samples were submitted to an L. monocytogenes count according to the procedure described by AOAC (1995). The results were presented in log cfu per gram of meat (log cfu. $\mathrm{g}^{-1}$ of meat) (Oliveira et al., 2010). All antimicrobial assays were carried out in triplicate, and the results are expressed as an average of the three parallel assays.

\section{Statistical analysis}

Statistical analysis was performed to determine the significance of differences between groups $(\mathrm{p}<0.05)$ using 
the Tukey test to estimate the time of inactivation. Statistica software version 7.0 (StatSoft Inc., USA) was used for the data analysis.

\section{Results and Discussion}

Figures 1, 2 and 3 show the effects of MIC/2, MIC and 2xMIC of $C$. blanchetianus Baill essential oil on the viability of the bacteria of interest in food. The survival curve is presented as a way to measure the capacity of a compound to act on the viability of a microorganism. Furthermore, it may be inferred that the estimated mortality of a microbial population (determined by the number of viable cells on the plates) at a given concentration of an antimicrobial compound reflects the speed of the bactericidal effect or the duration of a bacteriostatic effect (Burt, 2004).

Three bacterial strains were selected for this test (Aeromonas hydrophila, Listeria monocytogenes and Salmonella Enteritidis), and the inhibition results of antimicrobial tests were used as the inclusion criteria. All of the growth curves obtained showed different activities for the different values of MIC. MIC and 2x MIC exhibited statistically significant inhibition of pathogen growth $(p<0.05)$ compared with the control sample.

Figure 1 shows that the microbial population size found at the last time interval analysed (10 hours) was approximately $10^{3} \mathrm{cfu} \cdot \mathrm{mL}^{-1}$, representing a reduction of 3-4 orders of magnitude in the number of viable cells relative to the initial inoculum. In turn, the microbial population size of the control sample was between $10^{9}$ and $10^{10} \mathrm{cfu} \cdot \mathrm{mL}^{-1}$ at time interval of $10 \mathrm{~h}$, an approximately 100 - to 1000 -fold increase from the value of the initial inoculum. MIC was more effective in inhibiting the growth of bacterial strains after 8 hours of interaction, MIC/2 after at least 10 hours

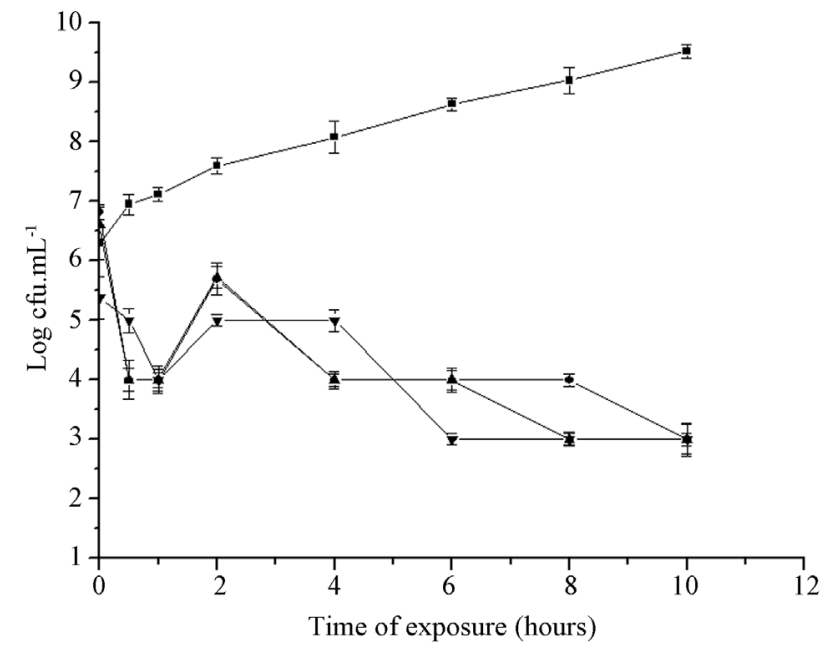

Figure 1 - Effect of the Croton blanchetianus Baill essential oil on the cell

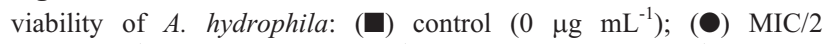
$\left(10 \mu \mathrm{g} \cdot \mathrm{mL}^{-1}\right) ;(\boldsymbol{\Delta}) \mathrm{MIC}\left(20 \mu \mathrm{g} \cdot \mathrm{mL}^{-1}\right) ;(\boldsymbol{\nabla}) 2 \mathrm{x}$ MIC $\left(40 \mu \mathrm{g} \cdot \mathrm{mL}^{-1}\right)$ of essential oil. and 2x MIC after only 6 hours. A compound is recognised as having a strong bactericidal effect when it is capable of causing a 1000-fold reduction (3 orders of magnitude, or 99.9\%) of the initial inoculum (LaPlante, 2007).

Figure 2 shows evidence of the bacteriostatic action (reduction of growth rate) of $C$. blanchetianus Baill essential oil against the bacterial strain studied. This bacteriostatic action was evident throughout the entire period of interaction (10 hours). The bacteriostatic activity is characterised by the ability of a substance to render a bacterium incapable of growing/multiplying in the broth but still capable of growth when removed from the broth and plated on appropriate agar (Smith-Palmer et al., 1998).

Some foodborne pathogens may show an initial exponential decrease in growth capacity followed by a subsequent increase in antimicrobial resistance upon exposure to compounds with antimicrobial properties (Rowan, 1999). This phenomenon occurs when the resistant microbial cells that represent only a small proportion of the initial microbial population are selected for and ultimately contribute a greater proportion of the total final population (Rowan, 1999).

Evidence that this phenomenon occurred in our experiments may be observed in Figure 2, in which an exponential reduction of the microbial population is observed from 0-8 hours of interaction, followed by a smaller reduction effect and an ascending growth curve up to 10 hours of interaction.

Figure 3 demonstrates a strong bactericidal effect in that the microbial population found in the last time interval analysed (10 hours) present values of approximately $10^{3}$ cfu. $\mathrm{mL}^{-1}$, a decrease of $3-5$ orders of magnitude in the number of viable cells relative to the initial inoculum. In turn, the control sample showed a microbial population of between $10^{8}$ and $10^{9} \mathrm{cfu} . \mathrm{mL}^{-1}$ at $10 \mathrm{~h}$, that is, an increase of

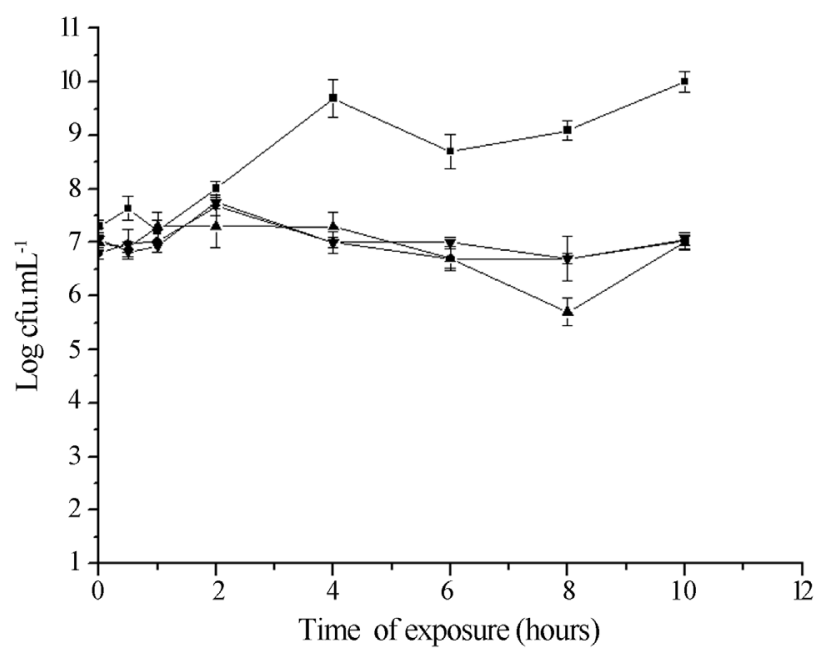

Figure 2 - Effect of the Croton blanchetianus Baill essential oil on the cell

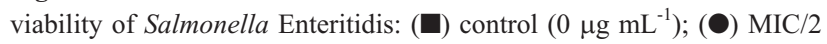
$\left(20 \mu \mathrm{g} \cdot \mathrm{mL}^{-1}\right) ;(\boldsymbol{\Delta}) \mathrm{MIC}\left(40 \mu \mathrm{g} \cdot \mathrm{mL}^{-1}\right) ;(\boldsymbol{\nabla}) 2 \mathrm{x}$ MIC $\left(80 \mu \mathrm{g} \cdot \mathrm{mL}^{-1}\right)$ of essential oil. 


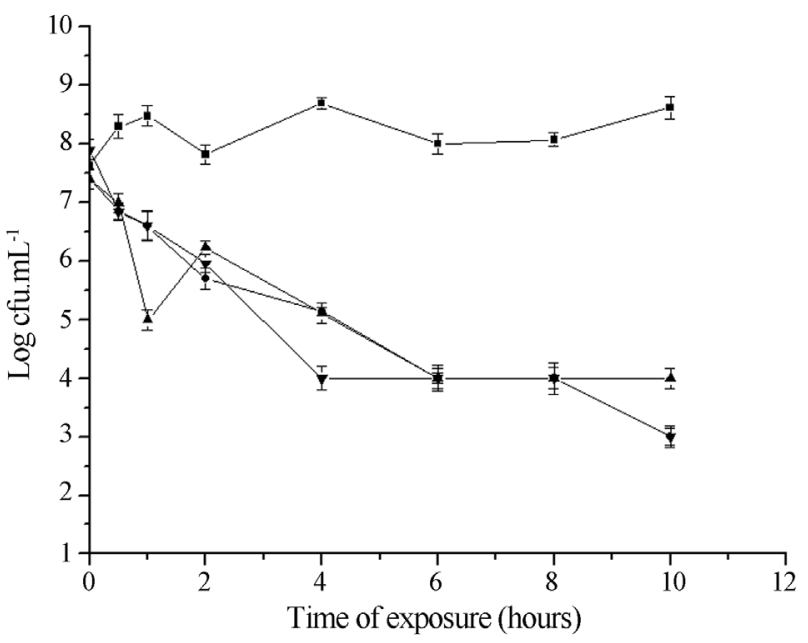

Figure 3 - Effect of the Croton blanchetianus Baill essential oil on the cell

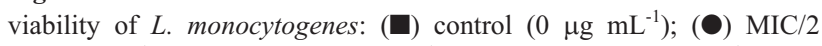
$\left(0.6 \mu \mathrm{g} \cdot \mathrm{mL}^{-1}\right) ;(\mathbf{\Delta}) \mathrm{MIC}\left(1.25 \mu \mathrm{g} \cdot \mathrm{mL}^{-1}\right) ;(\boldsymbol{\nabla}) 2 \mathrm{x}$ MIC $\left(2.5 \mu \mathrm{g} \cdot \mathrm{mL}^{-1}\right)$ of essential oil.

approximately 10 to 100 times the value found in the initial inoculum. The greatest efficacy of essential oil in inhibiting the growth of bacterial strains was observed after 4 hours of exposure to the oil in $2.5 \mu \mathrm{g} \cdot \mathrm{mL}^{-1}$, and 6 hours in 0.6 and $1.25 \mu \mathrm{g} . \mathrm{mL}^{-1}$ of essential oil. Thus, a significant reduction $(\mathrm{p}<0.05)$ in bacteria count was promoted in comparison with the control sample. We also observed a prolonged lag phase (stationary phase) of the bacterial growth curve. The lag phase is typically considered an indicator of the time required to adapt to a new environment; therefore, the longer the lag phase, the more difficult it is for the microorganism to adapt to the new environment and establish exponential growth (Souza et al., 2005).

Even though a satisfactory antimicrobial efficacy was found for the MIC of C. blanchetianus Baill essential oil, particularly against L. monocytogenes, Figure 4 shows when applied to food model, it did not decrease the number of microbes relative to the initial inoculum, as observed in vitro; however, there was a bacteriostatic effect at all concentrations tested. Growth inhibition was more effective at MIC and 10x MIC, which maintained the initial contamination level of $10^{5}$ cfu.mL $\mathrm{mL}^{-1}$ until the end of 4 days.

It must be noted that higher concentrations of essential oil are generally needed in food to achieve antimicrobial effectiveness similar to that obtained in laboratory experiments. In studies with food models, the required concentration values were two times higher in semi-skim milk (Karatzas et al., 2001), ten times in pork sausages (Pandit and Shelef, 1994), fifty times in a soup (Ultee and Smid, 2001) and twenty-five to one hundred times in cheese (Mendoza-Yepez et al., 1997). Our results showed that the effective inhibition of Listeria monocytogenes growth in meat required a concentration ten times higher than that used in the in vitro experiment.

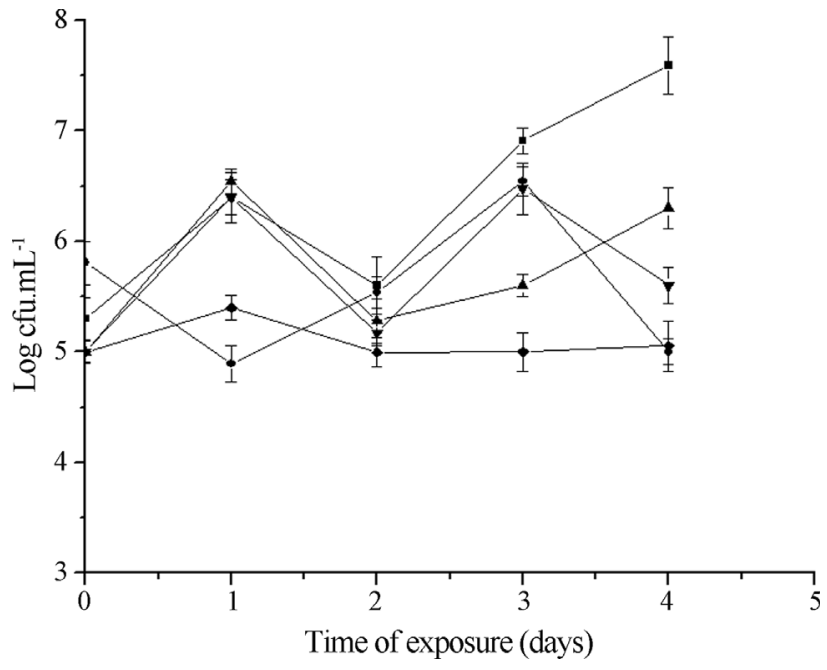

Figure 4 - Effect of the Croton blanchetianus Baill essential oil on the cell viability of $L$. monocytogenes on pieces of meat during storage under refrigeration for 5 days: (ם) control $\left(0 \mu \mathrm{g} \cdot \mathrm{g}^{-1}\right)$; ( $)$ MIC $\left(1.25 \mu \mathrm{g} \mathrm{g}^{-1}\right)$;

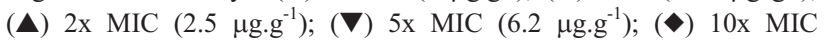
$\left(12.5 \mu \mathrm{g} . \mathrm{g}^{-1}\right)$ of essential oil.

The mechanism responsible for the lower antimicrobial effectiveness of essential oils when used in foods is still not well established (Gil et al., 2002). It has been suggested that the great variety of nutrients available in foods compared with culture medium could allow the microbial cell to recover more quickly from cell damage (Gil et al., 2002). It is also possible that the essential oil is dissolved in the lipid phase of the food, making it less capable of acting against the microorganisms present in the aqueous phase (Mejholm and Dalgaard, 2002).

In food model systems, both the intrinsic properties of the food and extrinsic determinants may influence the antimicrobial effectiveness of essential oils. According to reports from Gutierrez, Barry-Ryan and Bourke (Gutierrez et al., 2008; Gutierrez et al., 2009), various essential oils applied alone or in combination were more effective against pathogenic bacteria when applied in a medium with high protein content and high acidity, low levels of fats and carbohydrates, and moderate levels of simple sugars. Therefore, the Figure 3 demonstrates the model meat food used in the present experiment should not have interfered substantially in the antimicrobial effectiveness of the essential oil. Parallel results suggested that a longer period of exposure of the microorganism to the essential oil might be necessary to obtain a better understanding of the antibacterial kinetics.

\section{Conclusion}

It was concluded that the essential oil of $C$. blanchetianus Baill is effective as an antimicrobial agent in vitro; however, in a model system using fresh meat, its efficacy was reduced, and consequently a higher concentration of essential oil was required to inhibit bacterial growth. A 
major challenge for the practical application of essential oils as food preservatives is to optimise the use of essential oil at low concentrations in conjunction with other conservation techniques that enable food security and longer shelf lives.

\section{Acknowledgments}

We thank CAPES (Brazilian Federal Agency for Support and Evaluation of Graduate Education) for the financial support.

\section{Referências}

Abreu AS, Barbosa PS, Müller AH, Guilhon GMSP (2001) Constituintes químicos do caule e das cascas do caule de Croton pullei var Glabrior (Euphorbiaceae). Rev Virt Iniciação Científica 1:1-9.

AOAC International (1995) Official Methods of Analysis. 16th ed. AOAC International, Arlington, section 975.55.

Barbosa-Filho JM, Vasconcelos THC, Alencar AA, Batista LM, Oliveira RAG, Guedes DN, Falcão HS, Moura MD, Diniz MFF, Modesto-Filho J (2005) Plants and their active constituents from South, Central, and North America with hypoglycemic activity. Rev Bras Farmacogn 15:392-413.

Barros JC de, Conceição ML da, Gomes Neto NJG, Costa ACV da, Siqueira Júnior JP, Basílio Junior ID, Souza EL de (2009) Interference of Origanum vulgare L. essential oil on the growth and some physiological characteristics of Staphylococcus aureus strains isolated from foods. Lebensm.-Wiss u.-Technol 42:1139-1143.

Baydar H, Sagdiç O, Ozkan G, Karadogan T (2004) Antibacterial activity and composition of essential oils from Origanum, Thymbra and Sartureja species with commercial importance in Turkey. Food Control 15:169-172.

Benkeblia N (2004) Antimicrobial activity of essential oil extracts of various onions (Allium cepa) and garlic (Allium sativum). Lebensm.-Wiss u.-Technol 37:263-268,

Bennis S, Chami F, Chami N, Bouchikhi T, Remma A (2004) Surface alteration of Saccharomyces cerevisiae induced by thymol and eugenol. Lett Appl Microbiol 38:454-458.

Burt S (2004) Essential oils: their antibacterial properties and potential applications in food - a review. Int J Food Microbiol 94:223-253.

Chaves SAM, Reinhard KJ (2003) Palespharmacology and Pollen: Theory, Method, and Application. Mem Inst Oswaldo Cruz 98:207-11.

Daferera DJ, Ziogas BN, Polissiou MG (2003) The effectiveness of plant essential oils on the growth of Botrytis cinerea, Fusarium sp. and Clavibacter michiganensis subsp. michiganensis. Crop Protect 22:39-44.

European Pharmacopoeia (2004) Council of Europe: Strasbourg Cedex, 5th ed., 217-218 France 2.8.12.

Gil AO, Delaquis P, Russo P, Holley RA (2002) Evaluation of antilisterial action of cilantro oil on vaccum packed ham. Int J Food Microbiol 73:83-89.

Govaerts R, Frodin DG, Radcliffe-Smith A (2000) World checklist and bibliography of Euphorbiaceae. 4 vols. Kew: Royal Botanic Gardens.
Gutierrez J, Barry-Ryan C, Bourke P (2008) The antimicrobial efficacy of plant essential oil combinations and interactions with food ingredients. Int J Food Microbiol 124:91-97.

Gutierrez J, Barry-Ryan C, Bourke P (2009) Antimicrobial activity of plant essential oils using food model media: efficacy, synergistic potential and interactions with food components. Food Microbiol 26:142-150.

Karatzas AK, Kets EPW, Smid EJ, Bennik MHJ (2001) The combined action of carvacrol and high hydrostatic pressure on Listeria monocytogenes Scott A. J Appl Microbiol 90:463369.

LaPlante KL (2007) In vitro activity of lysostaphin, mupirocin, and tea tree oil against clinical methicillin-resistant Staphylococcus aureus. Diagn Microbiol Infect Dis 57:413-418.

Mann CM, Markham JL (1998) A new method for determining the minimum inhibitory concentration of essential oils. J Appl Microbiol 84:538-544.

Marino M, Bersani C, Comi G (2001) Impedance measurements to study the antimicrobial activity of essential oils from Lamiaceae and Compositae. Int J Food Microbiol 67:187195.

McChesney JD, Clark AM, Silveira ER (1991) Antimicrobial diterpenes of Croton sonderiaus, L, Hardwickic and 3,4Secotrachylobanoic acids. J Nat Prod 54:1625-1633.

Mejholm O, Dalgaard P (2002) Antimicrobial effect of essential oils on the seafood spoilage micro-organisms Photobacterium phosphoreum in liquid media and fish products. Lett Appl Microbiol 34:27-31.

Mendoza-Yepez MJ, Sanchez-Hidalgo LE, Maertens G, MariniIniesta F (1997) Inhibition of Listeria monocytogenes and other bactéria by plant essential oil (DMS) on Spanish soft cheese. J Food Saf 17:47-55.

Nair MKN, Vasudevan P, Venkitanarayanan K (2005) Antibacterial effect of black seed oil on Listeria monocytogenes. Food Control 16:395-398.

Oliveira CEV de, Stamford TLM, Gomes Neto NJ, Souza EL de (2010) Inhibition of Staphylococcus aureus in broth and meat broth using synergies of phenolics and organic acids. Int J Food Microbiol 137:312-316.

Palmeira-Junior SF, Alves FSM, Vieira LFA, Conversa LM, Lemos RPL (2006) Chemical constituents from the leaves and stems of Croton sellowii (Euphorbiaceae). Rev Bras Farmacogn 16:397-402.

Pandit VA, Shelef LA (1994) Sensitivity of Listeria monocytogenes to rosemary (Rosmarinus officinalis L.). Food Microbiol 11:57-63, 1994.

Radhrakrishanan-Sridhar S, Velusamy-Rajagopal R, Ramasamy-Rajavel R (2003) Antifungal activity of some essential oils. J Agric Food Chem 51:7596-7599.

Rowan NJ (1999) Evidence that inimical food-preservation barriers alter microbial resistance, cell morphology and virulence. Trends Food Sci Technol 10:251-270.

Salatino A, Salatino MLF, Negri G (2007) Traditional uses, Chemistry and pharmacology of Croton species (Euphorbiaceae). J Braz Chem Soc 18:11-33.

Seidil PR (2000) Pharmaceuticals from natural products. An Acad Brasil Cien 74:145-1500.

Smith-Palmer A, Stewart J, Fyfe L (1998) Antimicrobial properties of plant essential oils and essences against five impor- 
tant food-borne pathogens. Lett Food Microbiol 26:118122.

Souza EL, Lima EO, Freire KRL, Sousa CP (2005) Inhibition action of some essential oils and phytochemicals on the growth of moulds isolated from foods. Braz Arch Biol Technol 2:245-250.

Trabulsi LR, Alterthum F, Gompertz OF, Caneias JAN (2002) Microbiologia. (3ed). Rio de Janeiro: Atheneu.
Ultee A, Smid EJ (2001) Influence of carvacrol on growth and toxin production by Bacillus cereus. J Food Microbiol 64:373-378.

Valero M, Salmerón MC (2003) Antibacterial activity of 11 essential oils against Bacillus cereus in tyndallized carrot broth. Int J Food Microbiol 85:73-81.

All the content of the journal, except where otherwise noted, is licensed under a Creative Commons License CC BY-NC. 